\title{
Aluminum Melt Filtration with Carbon Bonded Alumina Filters
}

\author{
Claudia Voigt ${ }^{1, *}$, Jana Hubálková ${ }^{1}\left(\mathbb{D}\right.$, Tilo Zienert ${ }^{1}\left(\mathbb{D}\right.$, Beate Fankhänel $^{2}{ }^{(\mathbb{D}}$, Michael Stelter ${ }^{2}$, \\ Alexandros Charitos ${ }^{2}$ and Christos G. Aneziris ${ }^{1}$ \\ 1 Institute of Ceramic, Glass and Construction Materials, Technische Universität Bergakademie Freiberg, \\ Agricolastraße 17, 09599 Freiberg, Germany; jana.hubalkova@ikgb.tu-freiberg.de (J.H.); \\ tilo.zienert@ikgb.tu-freiberg.de (T.Z.); aneziris@ikgb.tu-freiberg.de (C.G.A.) \\ 2 Institute for Nonferrous Metallurgy and Purest Materials, Technische Universität Bergakademie Freiberg, \\ Leipziger Straße 34, 09599 Freiberg, Germany; beate.fankhaenel@inemet.tu-freiberg.de (B.F.); \\ stelter@inemet.tu-freiberg.de (M.S.); alexandros.charitos@inemet.tu-freiberg.de (A.C.) \\ * Correspondence: claudia.voigt@ikgb.tu-freiberg.de
}

Received: 17 August 2020; Accepted: 4 September 2020; Published: 7 September 2020

\begin{abstract}
The wetting behavior was measured for $\mathrm{Al}_{2} \mathrm{O}_{3}-\mathrm{C}$ in contact with AlSi7Mg with a conventional sessile drop test (vacuum, $950{ }^{\circ} \mathrm{C}$ and $180 \mathrm{~min}$ ) and a sessile drop test with a capillary purification unit (vacuum, $730{ }^{\circ} \mathrm{C}$ and $30 \mathrm{~min}$ ). The conventional test yielded contact angles of around $92^{\circ}$, whereas the sessile drop measurement with capillary purification showed a strongly non-wetting behavior with a determined apparent contact angle of the rolling drop of $157^{\circ}$. Filtration tests, which were repeated twice, showed that the $\mathrm{Al}_{2} \mathrm{O}_{3}-\mathrm{C}$ filter possessed a better filtration behavior than the $\mathrm{Al}_{2} \mathrm{O}_{3}$ reference filter. For both filtration trials, the PoDFA (porous disc filtration analysis) index of the $\mathrm{Al}_{2} \mathrm{O}_{3}-\mathrm{C}$ filter sample was equal to half of the PoDFA index of the $\mathrm{Al}_{2} \mathrm{O}_{3}$ reference filter sample, indicating a significantly improved filtration performance when using $\mathrm{Al}_{2} \mathrm{O}_{3}-\mathrm{C}$ filter. Notable is the observation of a newly formed layer between the aluminum and the $\mathrm{Al}_{2} \mathrm{O}_{3}-\mathrm{C}$ coating. The layer possessed a thickness between $10 \mu \mathrm{m}$ up to $50 \mu \mathrm{m}$ and consisted of $\mathrm{Al}, \mathrm{C}$, and $\mathrm{O}$, however, with different ratios than the original $\mathrm{Al}_{2} \mathrm{O}_{3}-\mathrm{C}$ coating. Thermodynamic calculations based on parameters of the wetting and filtration trials underline the possible formation of an $\mathrm{Al}_{4} \mathrm{O}_{4} \mathrm{C}$-layer.
\end{abstract}

Keywords: filtration; aluminum melt; ceramic foam filter; $\mathrm{Al}_{2} \mathrm{O}_{3}-\mathrm{C}$; thermodynamics

\section{Introduction}

The filtration of metal melt with ceramic foam filters is the state of the art since the 1960s. Ceramic foam filters used for the filtration of aluminum and aluminum alloys are typically made of alumina $\left(\mathrm{Al}_{2} \mathrm{O}_{3}\right)$ or silicon carbide $(\mathrm{SiC})$ [1]. In comparison, for the filtration of steel melts, ceramic foam filters predominantly based on zirconia $\left(\mathrm{ZrO}_{2}\right)$ or carbon bonded alumina $\left(\mathrm{Al}_{2} \mathrm{O}_{3}-\mathrm{C}\right)$ are industrially applied [2]. $\mathrm{Al}_{2} \mathrm{O}_{3}-\mathrm{C}$ is a refractory material with a low thermal expansion, negligible sinter shrinkage and improved slagging resistance caused by the low wetting (high contact angle) between carbon-bonded alumina and metallic melts. The main drawback of $\mathrm{Al}_{2} \mathrm{O}_{3}-\mathrm{C}$ is the low resistance against oxidation at high temperatures.

According to the filtration trials conducted by Voigt et al., an increasing contact angle induces an enhanced filtration behavior [3]. Based on this assumption, the low wetting between the $\mathrm{Al}_{2} \mathrm{O}_{3}-\mathrm{C}$ and metal melts might be beneficial in terms of high filtration efficiency. $\mathrm{Al}_{2} \mathrm{O}_{3}-\mathrm{C}$ materials are comprised of alumina, carbon fillers (e.g., carbon black and graphite) and carbon binders (e.g., pitch, tar, or phenolic resin), as well as appropriate additives [4]. The replica technique, based on coating of a polymeric template with a ceramic slurry followed by multi-step thermal treatment (drying, burning out of the 
polymer, sintering or coking), has been proved suitable for the production of ceramic foam filters based on $\mathrm{Al}_{2} \mathrm{O}_{3}-\mathrm{C}[5,6]$.

The aim of this study was to correlate the results of industrially conducted aluminum filtration trials using $\mathrm{Al}_{2} \mathrm{O}_{3}-\mathrm{C}$ ceramic foam filters with the wetting behavior of $\mathrm{Al}_{2} \mathrm{O}_{3}-\mathrm{C}$ substrates by aluminum.

For the determination of the wetting behavior and contact angle between solids and metal melts, the sessile drop technique is often used due to the relatively simple experimental setup. The testing procedure comprises the placing of a piece of metal on the substrate and subsequent heating in a furnace. During the heating and dwelling time, the metal drop shape is recorded and analyzed [7].

The determination of the contact angle of aluminum melt is influenced by numerous factors, on the part of aluminum (amount of impurities and alloying elements), testing conditions (atmosphere, temperature and time) as well as the part of the substrate (surface roughness, phase composition, crystal orientation and chemical heterogeneity) [8-10]. A strong impact on the measured contact angle is given by the affinity of aluminum to oxygen and, therefore, the formation of an alumina skin.

Even nano-scaled oxide skins cause a systematically higher and nearly constant contact angle. To remove the oxide skin, temperatures higher than $950{ }^{\circ} \mathrm{C}$, adequate vacuum and relatively long dwelling times are necessary [11]. Such conditions entail the application of temperature being approx. $200^{\circ} \mathrm{C}$ higher than the conventional aluminum filtration temperature (between $650{ }^{\circ} \mathrm{C}$ and $750{ }^{\circ} \mathrm{C}$ ), of different atmosphere (filtration trials are conducted under air) and of longer dwelling times. The conditions equivalent to the real aluminum filtration are feasible only using a sessile drop facility equipped with a capillary purification unit, where the aluminum metal is melted separately from the substrate. After melting, an oxide skin-free aluminum is dropped onto the substrate, since the oxide skin remains in the dropping unit, which allows the application of temperature lower than $950{ }^{\circ} \mathrm{C}$ [10].

The focus of the paper lies on the filtration of aluminum alloy melt. According to Damoah et al. [12], the filtration depends on multi-facetted parameters such as metal melt parameters (temperature, viscosity and composition), inclusion parameters (structure, size, number and chemistry), process parameters (melt velocity, casting design, melt preparation), and filter parameters (geometry, functional pore size, relative porosity, wetting behavior, chemistry). Despite the application of ceramic foam filters since the 1970s, there is little information about the influence of the filter chemistry on the filtration performance. Görner et al. [13] applied a filter with an $\mathrm{AlF}_{3}$ surface for filtering of $\mathrm{Na}$ and $\mathrm{Mg}$ from aluminum melts and achieved a Na removal of $80 \%$ to $91 \%$. Zhou et al. [14] tested an enamel coating and observed an improvement of tensile strain and a decrease of inclusions with a size of $6 \mu \mathrm{m}$. A $\mathrm{NaBr}$ coating was used by Luyten et al. [15] for the filtration of intermetallic phases with negative outcomes since large needle-shaped intermetallic phases blocked the coated filter and resulted in a cold run. The aforementioned papers investigated coatings not being used in the industry. In contrast, Syvertsen et al. [16] compared the filtration behavior of two commercially available and industrial used filters types $\mathrm{Al}_{2} \mathrm{O}_{3}$ and $\mathrm{SiC}$ both in laboratory and industrial scale. The LiMCA measurements yielded higher filtration efficiencies for filters made of $\mathrm{SiC}$. Voigt et al. [17] investigated filters made of the refractory materials $\mathrm{Al}_{2} \mathrm{O}_{3}, \mathrm{MgAl}_{2} \mathrm{O}_{4}, 3 \mathrm{Al}_{2} \mathrm{O}_{3} \cdot 2 \mathrm{SiO}_{2}$, and $\mathrm{TiO}_{2}$. The $3 \mathrm{Al}_{2} \mathrm{O}_{3} \cdot 2 \mathrm{SiO}_{2}$ showed the best filtration efficiencies for inclusions $<120 \mu \mathrm{m}$. As the $3 \mathrm{Al}_{2} \mathrm{O}_{3} \cdot 2 \mathrm{SiO}_{2}$ filters also yielded the highest surface roughness, a new issue concerning the role of the filter roughness raised. Further investigations showed a significant, directly proportional impact of the filter roughness on the filtration efficiency [18].

For the evaluation of the filtration behavior, the melt quality regarding the amount of non-metallic inclusions has to be evaluated. The PoDFA (porous disc filtration analysis) technique is often used for the determination of the quantity and nature of the non-metallic inclusions by pressing the aluminum melt through a fine-mesh sieve to collect the non-metallic inclusions of the investigated aluminum alloy melt (up to $3 \mathrm{~kg}$ ) in the filter cake and to enhance the concentration of the inclusions. After solidification of the aluminum within the filter, the filter including filter cake is cut out. A cross section is polished and analyzed by light microscopy. For reasons of comparability, it is necessary to entirely distinguish between the different inclusion phases (according to the color, morphology and size of the inclusions) and therefore apply a precise analysis specification describing all known characteristics. For the 
quantitative evaluation, a grid for the determination of the inclusion area is used so that the different kinds of inclusions can be quoted in $\mathrm{mm}^{2}$ inclusions per kilogram of analyzed aluminum. The amount and size of the oxide films is roughly estimated. Furthermore, it should be kept in mind that there are two kinds of PoDFA analysis, hot and cold. The hot PoDFA operates with aluminum melt samples taken directly from the process, whereas a cold PoDFA uses a solidified aluminum sample that has to be melted just before the test. The renewed melting needed for cold PoDFA might initiate the formation of further inclusions and oxide films, negatively affecting the analysis results [19,20].

\section{Materials and Methods}

\subsection{Preparation of the Ceramic Foams and Substrates}

For the investigation of the wetting and filtration behavior, two different sample geometries were necessary. The measurement of the contact angle was conducted using bulk substrates in the form of tablets having a diameter of $10 \mathrm{~mm}$ and a height of $6 \mathrm{~mm}$, whereas for the filtration trials, ceramic foam filters in the form of cuboids having an edge length of $50 \mathrm{~mm}$ and a height of $22 \mathrm{~mm}$ with 20 ppi (pores per inch) were applied. The results of the filtration and the wetting measurements were compared to pure $\mathrm{Al}_{2} \mathrm{O}_{3}$ filters and pure $\mathrm{Al}_{2} \mathrm{O}_{3}$ substrates used as reference materials. In order to be directly able to compare the filtration behavior of $\mathrm{Al}_{2} \mathrm{O}_{3}-\mathrm{C}$ filter with the reference, an equivalent functional pore size distribution was required. The real challenge is the sinter shrinkage of ceramic foam filters made of pure alumina during the thermal treatment. Contrary to pure alumina, $\mathrm{Al}_{2} \mathrm{O}_{3}-\mathrm{C}$ exhibits no significant shrinkage. For all investigations within this study, $\mathrm{Al}_{2} \mathrm{O}_{3}$ skeleton filters were used and coated with $\mathrm{Al}_{2} \mathrm{O}_{3}$ slurry (see Table 1 ) or $\mathrm{Al}_{2} \mathrm{O}_{3}-\mathrm{C}$ slurry (see Table 2) to prevent the differences in the functional pore size distribution caused by different shrinkage behavior.

Table 1. Composition and thermal treatment conditions for the preparation of $\mathrm{Al}_{2} \mathrm{O}_{3}$ coating. $\left({ }^{*}\right.$ based on sum of solids).

\begin{tabular}{|c|c|c|}
\hline Raw Materials and Thermal Treatment Conditions & Function & Fraction/wt. $\%$ \\
\hline $\mathrm{Al}_{2} \mathrm{O}_{3} \mathrm{CT} 9 \mathrm{FG}$ (Almatis, Ludwigshafen, Germany)/wt.\% & Refractory material & 33.3 \\
\hline $\mathrm{Al}_{2} \mathrm{O}_{3} \mathrm{CT} 3000$ SG (Almatis, Ludwigshafen, Germany)/wt.\% & Refractory material & 33.3 \\
\hline $\mathrm{Al}_{2} \mathrm{O}_{3}$ T60/T64 45 $\mathrm{m}$ (Almatis, Ludwigshafen, Germany)/wt.\% & Refractory material & 33.3 \\
\hline Optapix AC 170* (Zschimmer \& Schwarz, Lahnstein, Germany)/wt.\% & Binder & 1.0 \\
\hline Dolapix CE 64* (Zschimmer \& Schwarz, Lahnstein, Germany)/wt.\% & Dispersant & 0.6 \\
\hline Sintering temperature of the coating $/{ }^{\circ} \mathrm{C}$ & & 1600 \\
\hline Atmosphere & & oxidizing \\
\hline
\end{tabular}

Table 2. Composition and thermal treatment conditions for the preparation of $\mathrm{Al}_{2} \mathrm{O}_{3}-\mathrm{C}$ coating. ( ${ }^{*}$ based on sum of solids).

\begin{tabular}{ccc}
\hline Raw Materials and Thermal Treatment Conditions & Function & Fraction/wt. $\%$ \\
\hline $\mathrm{Al}_{2} \mathrm{O}_{3}$ Martoxid MR-70 (Martinswerk, Bergheim, Germany)/wt.\% & Refractory material & 66.0 \\
Coal pitch Carbores P (Rain Carbon, Castrop-Rauxel, Germany)/wt.\% & Binder & 20.0 \\
Carbon black N991 (Lehmann \& Voss \& Co., Hamburg, Germany)/wt.\% & Filler & 6.3 \\
Graphite AF 96-97 (Graphit Kropfmühl, Hauzenberg, Germany)/wt.\% & Filler & 7.7 \\
Ammonium ligninsulfonate* (Otto Dille, Norderstedt, Germany)/wt.\% & Binder + dispersant & 1.5 \\
MelPers ${ }^{\circledR} 9360^{*}$ (BASF, Ludwigshafen, Germany)/wt.\% & Dispersant & 0.3 \\
Contraspum K 1012* (Zschimmer \& Schwarz, Lahnstein, Germany)/wt.\% & Anti-foaming agent & 0.1 \\
Coking temperature of the coating/ ${ }^{\circ}$ C & 800 and 1400 \\
Atmosphere & reducing \\
\hline
\end{tabular}

The coatings were applied using a combined dip-spin technique where the $\mathrm{Al}_{2} \mathrm{O}_{3}$ skeleton was immersed completely in the slurry followed by a centrifugation step for the removal of excess slurry. The applied thermal treatment conditions are presented in Tables 1 and 2. 
The mechanical stability of the $\mathrm{Al}_{2} \mathrm{O}_{3}-\mathrm{C}$ coating on the $\mathrm{Al}_{2} \mathrm{O}_{3}$ skeleton filter was tested with a moderate impingement test comprising of the passage of $3 \mathrm{~kg}$ AlSi7Mg0.3 melt (Trimet Aluminium AG, Essen, Germany) through the filter. The drop height of the aluminum melt from the crucible to the filter was approximately $30 \mathrm{~cm}$ and the melt temperature was approximately $730^{\circ} \mathrm{C}$. The microstructure of the $\mathrm{Al}_{2} \mathrm{O}_{3}$-C-coated filter after the impingement test was evaluated by means of a scanning electron microscope XL 30 SEM (Philips, Eindhoven, Germany).

The substrates for the sessile drop tests were prepared by uniaxial pressing of the dried and crushed slurries $\left(\mathrm{Al}_{2} \mathrm{O}_{3}\right.$ and $\left.\mathrm{Al}_{2} \mathrm{O}_{3}-\mathrm{C}\right)$ as used for the coating of the ceramic foam filters. During the conventional sessile drop test, a coked and polished substrate surface was used. For the sessile drop test with capillary purification, a comparable surface roughness and quality for filters should be achieved. Thus, the uniaxially pressed substrates were dip coated with the coating slurry of the respective compositions. The thermal treatment of the substrates was performed in the same way as for the ceramic foam filters.

\subsection{Sessile Drop Tests}

Two types of sessile drop tests were conducted

- conventional sessile drop test and

- $\quad$ sessile drop test with capillary purification unit.

The conventional sessile drop test was performed at a high-temperature tube furnace with a high vacuum and an inert gas system (Carbolite Gero, Neuhausen, Germany) at the Institute for Nonferrous Metallurgy and Purest Materials (TU Bergakademie Freiberg, Freiberg, Germany). The aluminum alloy AlSi7Mg (Trimet Aluminium, Essen, Germany) was cut to masses between $90 \mathrm{mg}$ to $95 \mathrm{mg}$ immediately before the trial for attaining a thin oxide layer [21], and thereafter placed on the substrates $\left(\mathrm{Al}_{2} \mathrm{O}_{3}-\mathrm{C}\right.$ $800{ }^{\circ} \mathrm{C}$ and $\mathrm{Al}_{2} \mathrm{O}_{3}$ reference) at room temperature and positioned in the furnace. Before starting the heating procedure with $350{ }^{\circ} \mathrm{C} / \mathrm{h}$ to the temperature of $950{ }^{\circ} \mathrm{C}$, the furnace was evacuated to reach a pressure of $p \leq 1.5 \times 10^{-5} \mathrm{mbar}$. After a dwell time of $180 \mathrm{~min}$, the pressure of $p<(2.8 \pm 0.4) \times 10^{-5}$ mbar was achieved. Three measurements were conducted for the $\mathrm{Al}_{2} \mathrm{O}_{3}-\mathrm{C}$ substrates.

For the evaluation of the contact angle $\theta_{\text {cal }}$, following the equation valid for small droplets ( $m<100 \mathrm{mg}$ ), Equation (1):

$$
\theta_{c a l}=2 \arctan (2 h / d)
$$

was used [7]. The height $h$ and the diameter $d$ of the aluminum droplet were read off from the digital images recorded with a digital camera (The Imaging Source, Bremen, Deutschland).

The sessile drop tests with capillary purification unit were carried out at the Foundry Research Institute (Krakow, Poland) [22]. The aluminum alloy AlSi7Mg (Trimet Aluminium AG, Essen, Germany) was melted in a graphite syringe separately from the $\mathrm{Al}_{2} \mathrm{O}_{3}-\mathrm{C}$ substrate. At a temperature of $730{ }^{\circ} \mathrm{C}$ and a pressure $p<1 \times 10^{-5}$ mbar, an oxide-free droplet was placed on the substrate. The shape of the drop was recorded by high-resolution CCD camera with a rate of 100 images per minute.

\subsection{Filtration Trials}

The filtration trials were conducted at the metal foundry Georg Herrmann Metallgiesserei (Muldenhütten, Germany) with the aluminum alloy AlSi7Mg (EN AC-42100 from Rheinfelden Alloys (Rheinfelden, Germany), whereby the aluminum melt comprised 50\% ingots and 50\% scrap (recycled aluminum consisting of solidified feeders and runners) for the introduction of non-metallic inclusions. The quantity of $300 \mathrm{~kg}$ of aluminum alloy AlSi7Mg was electrically heated and skimmed after melting. The used sand mold consisted of a joint sprue, horizontal runners with filter chamber and vertical steel molds (coated with zircon coating), see Figure 1. 


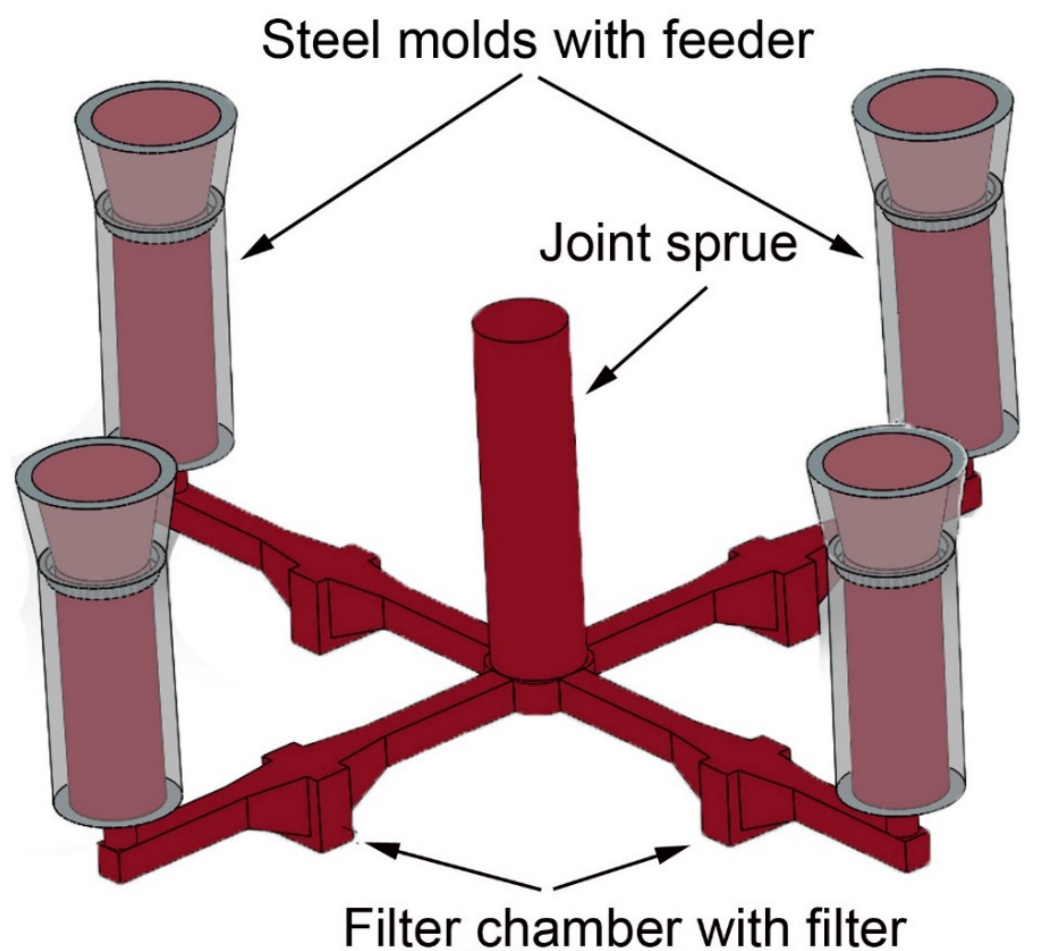

Figure 1. Casting system for the filtration trials with sand mold.

The joint sprue should equally distribute the incoming particle load and allow to compare the filtration results of four different filters in the same sand mold, and thus, with comparable melt quality. The investigated ceramic foam filters were tested in two different filtration trials. Filtration trial 1 involved:

- $\mathrm{Al}_{2} \mathrm{O}_{3}$ reference filter

- $\mathrm{Al}_{2} \mathrm{O}_{3}$ - $\mathrm{C}$ filter $\left(800^{\circ} \mathrm{C}\right)$

The filtration trial 2 with the following filters was conducted for repeatability reasons:

- $\mathrm{Al}_{2} \mathrm{O}_{3}$ reference filter

- $\mathrm{Al}_{2} \mathrm{O}_{3}$ rough filter

- $\mathrm{Al}_{2} \mathrm{O}_{3}-\mathrm{C}$ filter $\left(800^{\circ} \mathrm{C}\right)$

- $\mathrm{Al}_{2} \mathrm{O}_{3}-\mathrm{C}$ filter $\left(1400^{\circ} \mathrm{C}\right)$

After the solidification of the aluminum alloy, the casting was detached from the sand and the steel mold. The filters were cut out and embedded with epoxy resin, ground, polished and analyzed with the XL 30 SEM (Philips, Eindhoven, Germany) equipped with an energy-dispersive X-ray spectroscopy device (Phoenix, Weiterstadt, Germany). The aluminum in the steel mold was separated from the feeder and then analyzed regarding non-metallic inclusions with the help of a cold PoDFA analysis performed by HOESCH Metallurgical Service (Niederzier, Germany).

\subsection{Thermodynamic Calculations}

Thermodynamic calculations of chemical reactions between the aluminum melt and the investigated substrate under different experimental conditions were done using the software ThermoCalc [23] based on a self-developed database of the Al-Si-Mg-O-C system [24-26].

For the calculations, the interface systems were defined as follows. The interface melt/filter is simulated as a mole fraction of 0.5 atoms of melt and a mole fraction of 0.5 filter atoms. To study the influence of atmosphere, the system was expanded to the respective mole fractions of 0.25 melt atoms, 0.25 atmosphere atoms and 0.5 filter atoms. As nitrogen is not included in our thermodynamic 
description, air was simulated as a mixture of $\mathrm{Ar}$ and $\mathrm{O}$ with mole fractions of 0.79 and 0.21 , respectively. The composition of the melt is 92.508 at. $\% \mathrm{Al}, 6.813$ at. $\% \mathrm{Si}$ and 0.679 at.\% $\mathrm{Mg}$. The $\mathrm{Al}_{2} \mathrm{O}_{3}-30 \mathrm{wt} . \%-\mathrm{C}$ filter corresponds to a composition of 23.153 at. $\% \mathrm{Al}, 34.730$ at. $\% \mathrm{O}$ and 42.117 at. $\%$ C.

\section{Results}

\subsection{Preparation of the Ceramic Foams and Substrates}

SEM investigations of the $\mathrm{Al}_{2} \mathrm{O}_{3}$-C-coated filter after the moderate impingement test showed no extensive spalling, peeling or erosion of the coating. The $\mathrm{Al}_{2} \mathrm{O}_{3}-\mathrm{C}$ coating at the $\mathrm{Al}_{2} \mathrm{O}_{3}$ skeleton proved to be usable.

\subsection{Sessile Drop Tests}

The contact angles measured with the conventional sessile drop technique showed a typical curve progression comprising a decrease of the determined contact angle, see Figure 2.

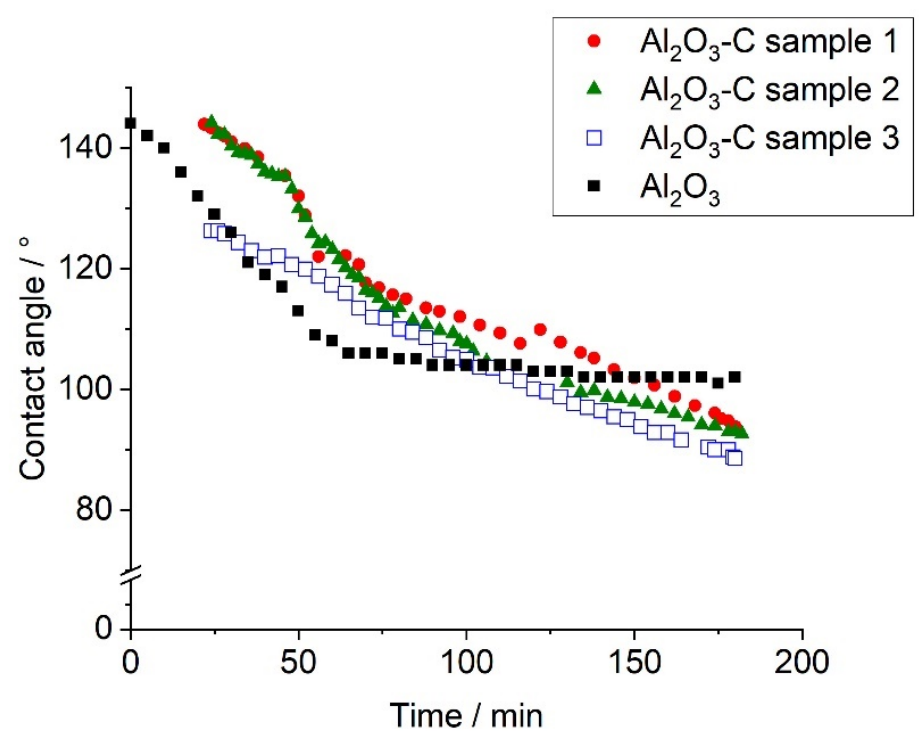

Figure 2. Time dependency of the contact angle determined by sessile drop measurement.

The contact angle of pure $\mathrm{Al}_{2} \mathrm{O}_{3}$ was above $140^{\circ}$ at the beginning of the dwell time at $950{ }^{\circ} \mathrm{C}$ and decreased systematically during the dwelling time down to an almost stable contact angle of $100^{\circ}$. The initial decrease of the contact angle indicated that the decomposition of the oxide skin on the aluminum alloy finalized when reaching a stable contact angle.

The $\mathrm{Al}_{2} \mathrm{O}_{3}$-C-coated substrates showed different progress with an almost linear decrease of the contact angle over the whole dwelling time without reaching a stable contact angle. The non-achievement of a stable contact angle for the $\mathrm{Al}_{2} \mathrm{O}_{3}-\mathrm{C}$ substrates can be caused by a reaction between the substrate and the aluminum melt, a strong evaporation of the aluminum melt or a diffusion of the aluminum into the $\mathrm{Al}_{2} \mathrm{O}_{3}-\mathrm{C}$ substrate. Investigations of the samples after the sessile-drop measurements showed that a reaction between the AlSi7Mg melt and the $\mathrm{Al}_{2} \mathrm{O}_{3}-\mathrm{C}$ substrate had taken place. No evidence of infiltration of the substrate within the metal could be found, see Figure 3.

On the contrary, the drops could be easily detached from the substrate, with reaction layers visible to the naked eye. Subsequent scanning electron microscopic and energy dispersive $\mathrm{X}$-ray spectroscopy investigations revealed an oxidic layer consisting of $\mathrm{Al}, \mathrm{O}, \mathrm{Si}$, and $\mathrm{C}$ on top of the $\mathrm{Al}_{2} \mathrm{O}_{3}-\mathrm{C}$ substrate at the former interface and at the bottom of the droplets, Figure 3.

In order to estimate the repeatability of the sessile drop measurements regarding carbon-containing materials, three $\mathrm{Al}_{2} \mathrm{O}_{3}$-C-coated substrates with the same composition and manufactured under the same conditions and coked at $800{ }^{\circ} \mathrm{C}$ (designated as $\mathrm{Al}_{2} \mathrm{O}_{3}-\mathrm{C}$ sample 1 to $\mathrm{Al}_{2} \mathrm{O}_{3}-\mathrm{C}$ sample 3) were 
measured. The three performed measurements revealed small differences in the initial stage but at dwell times larger than $150 \mathrm{~min}$, the curve progresses became comparable with total differences of only $6^{\circ}$ (contact angles of $89^{\circ}, 93^{\circ}$ and $95^{\circ}$ after $180 \mathrm{~min}$ ). Contact angles lower than $90^{\circ}$ [7] indicated a good wetting behavior contradicting the statement of the good slagging resistance due to a poor wetting. Fankhänel et al. [11] proved the occurrence of chemical reactions between several oxide ceramics and an AlSi7Mg alloy during the sessile drop measurements at $950{ }^{\circ} \mathrm{C}$ contrary to the measurements performed at $730{ }^{\circ} \mathrm{C}$ [3]. The substrate based on $\mathrm{MgAl}_{2} \mathrm{O}_{4}$ showed an impoverishment of $\mathrm{Mg}$ after the sessile drop measurements at $950{ }^{\circ} \mathrm{C}$, whereas the same substrate featured no chemical changes after the sessile drop measurements at $730{ }^{\circ} \mathrm{C}[3]$.
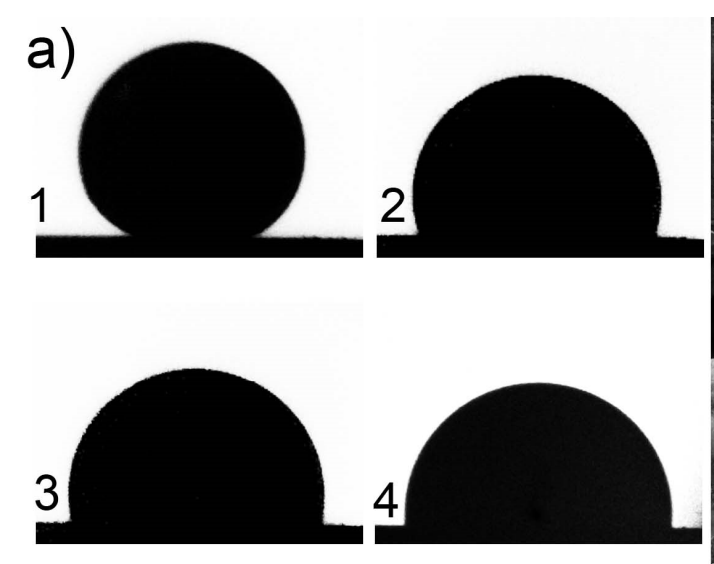

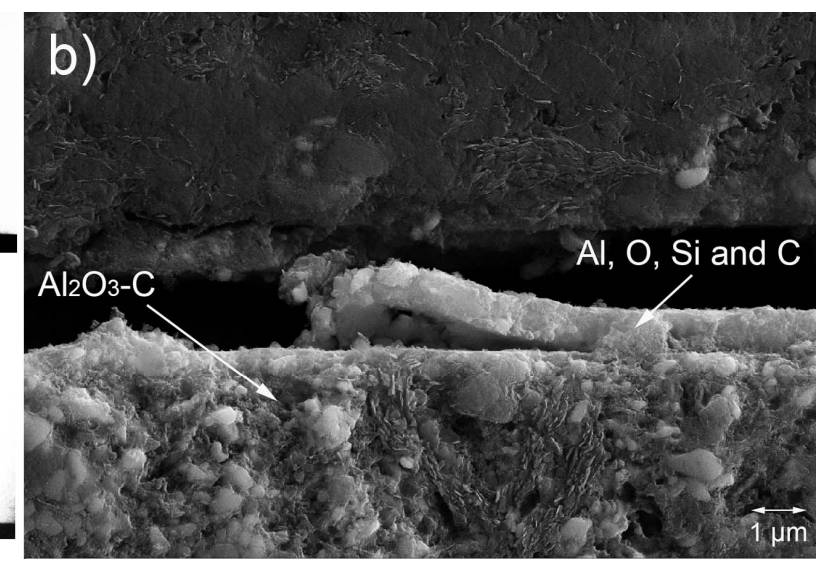

Figure 3. Conventional sessile drop experiment at $950{ }^{\circ} \mathrm{C}$. (a) Photo sequence of the sessile drop experiment, (b) SEM micrograph of the $\mathrm{Al}_{2} \mathrm{O}_{3}-\mathrm{C}$ sample after conventional sessile drop test with $\mathrm{AlSi7Mg}$ with interfacial layer without AlSi7Mg drop due missing attachment between drop and substrate.

Therefore, sessile drop measurements with a capillary purification unit at $730{ }^{\circ} \mathrm{C}$ were conducted additionally. The greatest challenge of this measurement was the placing of the aluminum droplet at the substrate as the aluminum droplet tended to provide a springing (jumping) movement at the substrate surface before rolling away, see Figure 4.

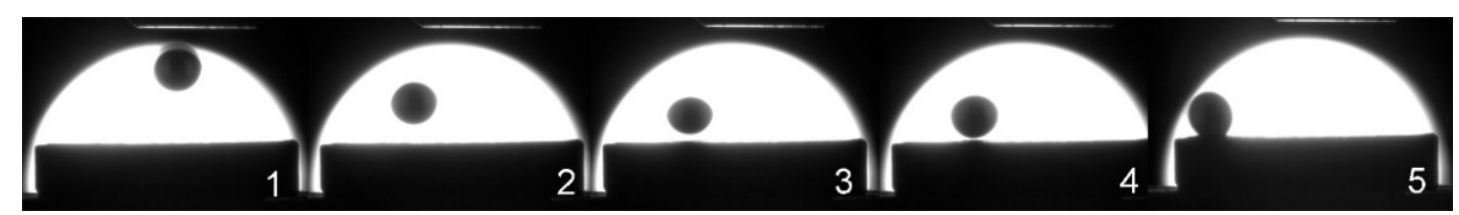

Figure 4. Photo sequence of the sessile drop experiment on $\mathrm{Al}_{2} \mathrm{O}_{3}-\mathrm{C}$ substrate with capillary purification of AlSi7Mg alloy-Measurement 1.

The repulsive interaction indicates a strong non-wetting behavior between $\mathrm{Al}_{2} \mathrm{O}_{3}-\mathrm{C}$ and $\mathrm{AlSi} \mathrm{Mg}$. Preceding sessile drop measurements with substrates made of $\mathrm{Al}_{2} \mathrm{O}_{3}, \mathrm{MgAl}_{2} \mathrm{O}_{4}, 3 \mathrm{Al}_{2} \mathrm{O}_{3} \cdot 2 \mathrm{SiO}_{2}$, and $\mathrm{TiO}_{2}$ did not show such repulsive behavior [3].

A further sessile drop measurement with a modified capillary purification unit, which allows to squeeze and suck the aluminum melt, was carried out. By means of the modified unit, it was possible to lift and lower the syringe. Thus, better positioning of the aluminum droplet without fall and impingement was applicable. Despite this achievement, the aluminum droplet rolled again out of the $\mathrm{Al}_{2} \mathrm{O}_{3}-\mathrm{C}$ substrate, see Figure 5 . 


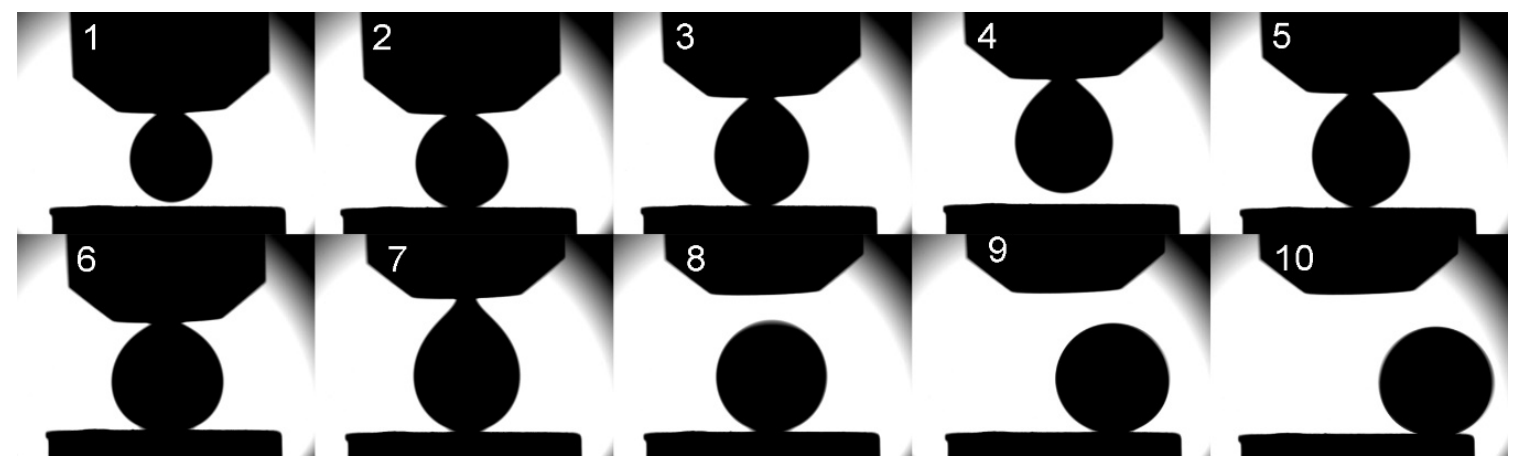

Figure 5. Sequence of photos of the sessile drop experiment on $\mathrm{Al}_{2} \mathrm{O}_{3}-\mathrm{C}$ substrate with capillary purification of AlSi7Mg alloy-Measurement 2.

Measurement 2 verified the repulsive interactions and hence a distinct non-wetting behavior between the $\mathrm{AlSi} / \mathrm{Mg}$ droplet and the $\mathrm{Al}_{2} \mathrm{O}_{3}-\mathrm{C}$ substrate. The determination of the apparent contact angle between $\mathrm{Al}_{2} \mathrm{O}_{3}-\mathrm{C}$ and the rolling AlSi7Mg droplet (three last images of Figure 5) yielded a value of $\left(157^{\circ} \pm 1^{\circ}\right)$, whereas the contact angle between $\mathrm{Al}_{2} \mathrm{O}_{3}$ and AlSi7Mg was measured to be $108^{\circ}$ [3].

The difference between the conventional sessile drop and the sessile drop with capillary purification clearly showed the importance of the testing conditions for determination of the contact angle by aluminum melt. Sessile drop measurements at higher temperatures might enhance reactions not occurring within an industrial aluminum filtration setup.

\subsection{Filtration Trials}

Two different filtrations trials were conducted to test the repeatability of the filtration trials. The filtrations trials were video recorded and showed an equal aluminum filling within $16 \mathrm{~s}$, indicating comparable filter flow rates.

The PoDFA analysis yields the amount of inclusions (area of inclusions in $\mathrm{mm}^{2}$ per kilogram analyzed aluminum) detected in the aluminum melt, i.e., the lower the amount of non-metallic inclusions in the aluminum sample, the lower the PoDFA index. The PoDFA index is the sum of the amounts of detected inclusions. Within filtration trial $1, \mathrm{Al}_{2} \mathrm{O}_{3}$ reference filter and $\mathrm{Al}_{2} \mathrm{O}_{3}-\mathrm{C}$ filter $\left(800{ }^{\circ} \mathrm{C}\right)$ were tested. Table 3 shows that $\mathrm{Al}_{2} \mathrm{O}_{3}$ films, carbides, magnesium oxide, spinel, refractory material, iron and manganese oxides, as well as grain refiner were detected in the castings.

Table 3. Results of the PoDFA analysis of the filtration trial 1, regarding the filtered melt.

\begin{tabular}{|c|c|c|}
\hline Inclusion Types & $\begin{array}{c}\mathrm{Al}_{2} \mathrm{O}_{3} \\
\text { Reference }\end{array}$ & $\begin{array}{c}\mathrm{Al}_{2} \mathrm{O}_{3}-\mathrm{C} \\
800{ }^{\circ} \mathrm{C}\end{array}$ \\
\hline $\begin{array}{c}\mathrm{Al}_{2} \mathrm{O}_{3} \text { films/number kg } \\
\text { (Length }<500 \mu \mathrm{m} \text {, thickness }<3 \mu \mathrm{m})\end{array}$ & 187 & 180 \\
\hline Carbides $/ \mathrm{mm}^{2} \mathrm{~kg}^{-1}$ & 0.006 & 0.003 \\
\hline Magnesium oxide $/ \mathrm{mm}^{2} \mathrm{~kg}^{-1}$ & 0.004 & 0.003 \\
\hline Spinel $/ \mathrm{mm}^{2} \mathrm{~kg}^{-1}$ & 0.198 & 0.076 \\
\hline Reacted refractory material (spinel related) $/ \mathrm{mm}^{2} \mathrm{~kg}^{-1}$ & 0.015 & 0.018 \\
\hline Non-reacted refractory material $\left(\alpha-\mathrm{Al}_{2} \mathrm{O}_{3}, \mathrm{CaO}, \mathrm{SiO}_{2}\right) / \mathrm{mm}^{2} \mathrm{~kg}^{-1}$ & 0.009 & 0.002 \\
\hline Iron and manganese oxides $/ \mathrm{mm}^{2} \mathrm{~kg}^{-1}$ & 0.005 & 0.003 \\
\hline Grain refiner $\mathrm{TiB}_{2} / \mathrm{mm}^{2} \mathrm{~kg}^{-1}$ & 0.009 & 0.001 \\
\hline PoDFA index (sum) $/ \mathrm{mm}^{2} \mathrm{~kg}^{-1}$ & 0.246 & 0.106 \\
\hline
\end{tabular}

The PoDFA index of the $\mathrm{Al}_{2} \mathrm{O}_{3}-\mathrm{C}$ filter sample was equal to half of the PoDFA index of the $\mathrm{Al}_{2} \mathrm{O}_{3}$ reference filter sample, indicating a significantly improved filtration when using $\mathrm{Al}_{2} \mathrm{O}_{3}-\mathrm{C}$ filter, which mainly resulted from the reduction of spinel inclusions, see Table 3. 
Within the scope of filtration trial 2, $\mathrm{Al}_{2} \mathrm{O}_{3}$ reference filter, $\mathrm{Al}_{2} \mathrm{O}_{3}$ rough filter, $\mathrm{Al}_{2} \mathrm{O}_{3}-\mathrm{C}$ filter $\left(800{ }^{\circ} \mathrm{C}\right)$, and $\mathrm{Al}_{2} \mathrm{O}_{3}-\mathrm{C}$ filter $\left(1400{ }^{\circ} \mathrm{C}\right)$ were tested. Due to a cold run of the $\mathrm{Al}_{2} \mathrm{O}_{3}$ reference filter (blockade of the filter) during filtration trial 2, in the following, the $\mathrm{Al}_{2} \mathrm{O}_{3}$ rough filter will be used as a reference filter. The substitution of the $\mathrm{Al}_{2} \mathrm{O}_{3}$ reference filter through the $\mathrm{Al}_{2} \mathrm{O}_{3}$ rough filter is justifiable given the fact that previous filtration trials demonstrated better filtration efficiencies for the $\mathrm{Al}_{2} \mathrm{O}_{3}$ rough filter in comparison with the $\mathrm{Al}_{2} \mathrm{O}_{3}$ reference filter [18].

The PoDFA results of filtration trial 2 exhibited inclusions of the same nature as for filtration trial 1 , see Table 4, as expected due to the application of the same aluminum alloy at the same conditions.

Table 4. Results of the PoDFA analysis of filtration trial 2, regarding the filtered melt.

\begin{tabular}{|c|c|c|c|}
\hline Inclusion Types & $\begin{array}{c}\mathrm{Al}_{2} \mathrm{O}_{3} \text { Reference } \\
\text { Rough }\end{array}$ & $\begin{array}{c}\mathrm{Al}_{2} \mathrm{O}_{3}-\mathrm{C} \\
800{ }^{\circ} \mathrm{C}\end{array}$ & $\begin{array}{l}\mathrm{Al}_{2} \mathrm{O}_{3}-\mathrm{C} \\
1400{ }^{\circ} \mathrm{C}\end{array}$ \\
\hline $\begin{array}{c}\mathrm{Al}_{2} \mathrm{O}_{3} \text { films/number kg } \\
\text { (Length }<500 \mu \mathrm{m} \text {, thickness }<3 \mu \mathrm{m})\end{array}$ & 66 & 65 & 106 \\
\hline Carbides $/ \mathrm{mm}^{2} \mathrm{~kg}^{-1}$ & & 0.019 & \\
\hline Magnesium oxide $/ \mathrm{mm}^{2} \mathrm{~kg}^{-1}$ & 0.055 & & 0.012 \\
\hline Spinel $/ \mathrm{mm}^{2} \mathrm{~kg}^{-1}$ & 0.076 & 0.029 & 0.070 \\
\hline Reacted refractory material (spinel related) $/ \mathrm{mm}^{2} \mathrm{~kg}^{-1}$ & 0.765 & 0.395 & 0.492 \\
\hline Non-reacted refractory material $\left(\alpha-\mathrm{Al}_{2} \mathrm{O}_{3}, \mathrm{CaO}, \mathrm{SiO}_{2}\right) / \mathrm{mm}^{2} \mathrm{~kg}^{-1}$ & 0.043 & 0.039 & 0.019 \\
\hline Non-reacted refractory material (Graphite) $/ \mathrm{mm}^{2} \mathrm{~kg}^{-1}$ & 0.12 & & \\
\hline Iron and manganese oxides $/ \mathrm{mm}^{2} \mathrm{~kg}^{-1}$ & & & 0.025 \\
\hline PoDFA index $(\mathrm{sum}) / \mathrm{mm}^{2} \mathrm{~kg}^{-1}$ & 1.06 & 0.482 & 0.618 \\
\hline
\end{tabular}

The PoDFA index of the filtered aluminum showed the lowest values for the $\mathrm{Al}_{2} \mathrm{O}_{3}-\mathrm{C}\left(800{ }^{\circ} \mathrm{C}\right)$ filter followed by the $\mathrm{Al}_{2} \mathrm{O}_{3}-\mathrm{C}\left(1400{ }^{\circ} \mathrm{C}\right)$ filter. As already mentioned, the temperatures noted in Table 2 refer to the coking temperature of the $\mathrm{Al}_{2} \mathrm{O}_{3}-\mathrm{C}$ coating. Inversely, the $\mathrm{Al}_{2} \mathrm{O}_{3}$ rough filter possessed the highest PoDFA index, indicating the lowest filtration performance within filtration trial 2.

Both Filtration trials were performed with the same amount of AlSi7Mg scrap material (50\%) for the addition of non-metallic inclusions. Due to differences in the production of the metal foundry Georg Herrmann Metallgiesserei (Muldenhütten, Germany), the scrap material introduced different amounts of non-metallic inclusions. Due to the strong influence of the amount of non-metallic inclusions on the filtration rate, there are differences in the PoDFA index between filtration trial 1 and 2. Nevertheless, filtration trials 1 and 2 yielded the same result: the $\mathrm{Al}_{2} \mathrm{O}_{3}-\mathrm{C}$ filter possessed a better filtration than the $\mathrm{Al}_{2} \mathrm{O}_{3}$ reference filter. The difference between the $\mathrm{Al}_{2} \mathrm{O}_{3}-\mathrm{C} 800{ }^{\circ} \mathrm{C}$ and $\mathrm{Al}_{2} \mathrm{O}_{3}-\mathrm{C} 1400{ }^{\circ} \mathrm{C}$ filter is not explainable at the moment. Possible reasons are differences in the roughness, the specific surface or the level of graphitization of the $\mathrm{Al}_{2} \mathrm{O}_{3}-\mathrm{C}$.

SEM micrographs of the filters with the solidified aluminum in BSE mode showed clearly the presence of non-metallic inclusions, see Figure 6.
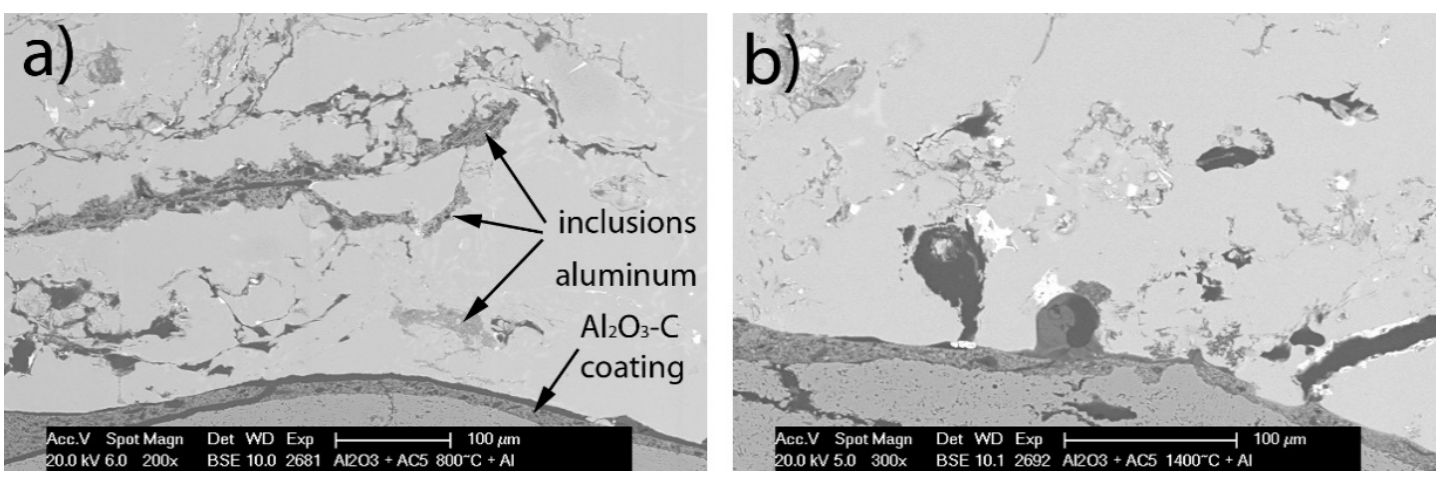

Figure 6. SEM micrographs of the (a) $\mathrm{Al}_{2} \mathrm{O}_{3}-\mathrm{C} 800{ }^{\circ} \mathrm{C}$ and (b) $\mathrm{Al}_{2} \mathrm{O}_{3}-\mathrm{C} 1400{ }^{\circ} \mathrm{C}$ after casting of $\mathrm{AlSi} \mathrm{Mg}$ with non-metallic inclusions. 
Notable is the observation of a newly formed boundary layer between the aluminum and the $\mathrm{Al}_{2} \mathrm{O}_{3}-\mathrm{C}$ coating, see Figure $7 \mathrm{~b}, \mathrm{c}$.
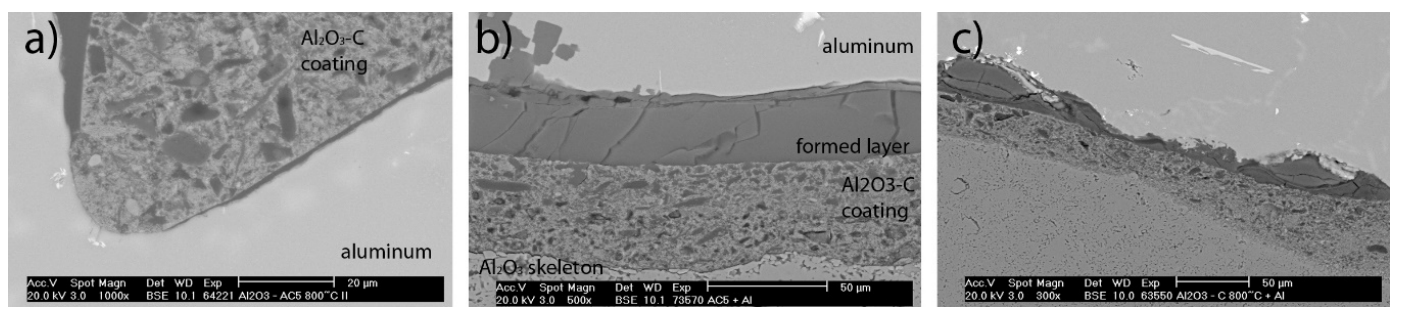

Figure 7. SEM micrographs of the (a) $\mathrm{Al}_{2} \mathrm{O}_{3}-\mathrm{C} 800{ }^{\circ} \mathrm{C}$, (b) $\mathrm{Al}_{2} \mathrm{O}_{3}-\mathrm{C} 1400{ }^{\circ} \mathrm{C}$ and $(\mathbf{c}) \mathrm{Al}_{2} \mathrm{O}_{3}$ rough filters after casting of AlSi7Mg with non-metallic inclusion.

It should be mentioned that such layers were not visible in each trial. In total, eight casting trials with $\mathrm{Al}_{2} \mathrm{O}_{3}-\mathrm{C}$ filters were conducted and four of them showed a clear formation of the boundary layer. The thickness varied between 10 and $50 \mu \mathrm{m}$. Figure 7a shows a filter without any boundary layer, whereas Figure $7 \mathrm{~b}, \mathrm{c}$ presents such a newly formed boundary, exhibiting different characteristics. The factors and the respective mechanism of boundary layer formation are unclear at the time of writing.

The newly formed boundary layer in Figure $7 \mathrm{~b}$ seemed to be very homogeneous. EDX analyses (Figure 8) of the $\mathrm{Al}_{2} \mathrm{O}_{3}-\mathrm{C}$ coating and the newly formed layer exhibited the same elements $\mathrm{C}, \mathrm{O}$, and $\mathrm{Al}$, but in different ratios.

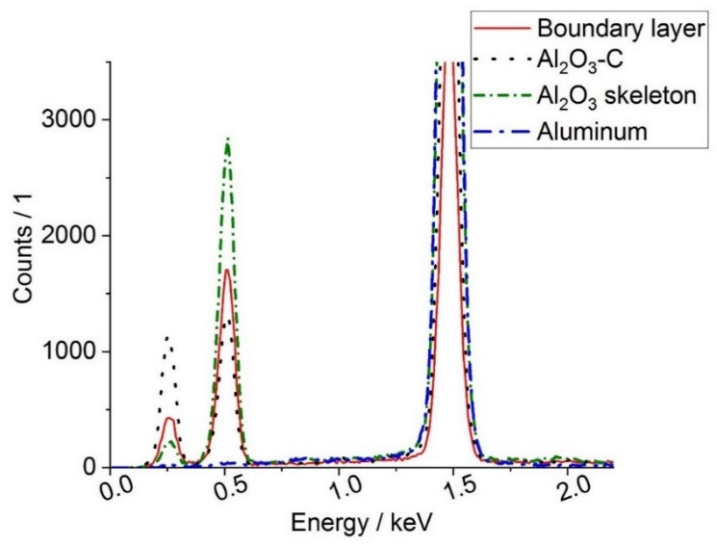

Figure 8. EDX analyses of the newly formed boundary layer (red), $\mathrm{Al}_{2} \mathrm{O}_{3}-\mathrm{C}$ coating (black), $\mathrm{Al}_{2} \mathrm{O}_{3}$ skeleton filter (green), and solidified aluminum (blue).

The newly formed layer features less $\mathrm{C}$, but more $\mathrm{O}$ than the $\mathrm{Al}_{2} \mathrm{O}_{3}-\mathrm{C}$ coating. An investigation of the newly formed boundary layers by means of EBSD revealed no electron backscatter patterns. The missing EBSD pattern might indicate the amorphous character of the newly formed layer. As the newly formed boundary layer showed characteristics of epoxy resin, epoxy resin free samples were tested showing the boundary layer as well. So embedding in epoxy resin can be excluded as reason for the boundary layer.

\subsection{Thermodynamic Calculations}

The results of thermodynamic calculations for the melt/filter interface at different conditions can be written as follows. At atmospheric pressure and a temperature of $740{ }^{\circ} \mathrm{C}$, the liquid partially reacts with the filter as, Equation (2):

$$
\begin{aligned}
0.5 \mathrm{~L}(\mathrm{Al}, \mathrm{Si}, \mathrm{Mg}) & +0.5 \text { filter } \\
& \rightarrow 3.89 \times 10^{-1} \mathrm{Al}_{8} \mathrm{SiC}_{7}+3.63 \times 10^{-1} \mathrm{Al}_{4} \mathrm{O}_{4} \mathrm{C}+2.26 \times 10^{-1} \mathrm{~L}(\mathrm{Al}, \mathrm{Si}, \mathrm{Mg}) \\
& +2.17 \times 10^{-2} \text { spinel }
\end{aligned}
$$


Whereas, under experimental vacuum conditions $\left(p=1 \times 10^{-5} \mathrm{mbar}\right)$ and a temperature of $730^{\circ} \mathrm{C}$, the formation of gas can be expected, Equation (3):

$0.5 \mathrm{~L}(\mathrm{Al}, \mathrm{Si}, \mathrm{Mg}) \quad+0.5$ filter

$$
\begin{aligned}
& \rightarrow 3.91 \times 10^{-1} \mathrm{Al}_{4} \mathrm{O}_{4} \mathrm{C}+3.82 \times 10^{-1} \mathrm{Al}_{8} \mathrm{SiC}_{7}+2.24 \times 10^{-1} \mathrm{~L}(\mathrm{Al}, \mathrm{Si}, \mathrm{Mg}) \\
& +3.53 \times 10^{-3} \operatorname{gas}\left(\mathrm{Mg}, \mathrm{Al}, \mathrm{Al}_{2} \mathrm{O}\right)
\end{aligned}
$$

With increasing temperature, the formation of gas is preferred under experimental vacuum $\left(p=1.5 \times 10^{-5}\right.$ mbar) and a temperature of $950^{\circ} \mathrm{C}$ as, Equation (4):

$$
\begin{aligned}
0.5 \mathrm{~L}(\mathrm{Al}, \mathrm{Si}, \mathrm{Mg}) & +0.5 \text { filter } \\
& \rightarrow 4.06 \times 10^{-1} \operatorname{gas}(\mathrm{Al}, \mathrm{CO}, \mathrm{Mg})+3.04 \times 10^{-1} \mathrm{Al}_{4} \mathrm{C}_{4} \mathrm{Si}+2.90 \times 10^{-1} \mathrm{Al}_{4} \mathrm{O}_{4} \mathrm{C}
\end{aligned}
$$

From Equations (2)-(4), one can expect chemical reactions at the melt/filter interface with possible formation of different carbides and the oxocarbide $\mathrm{Al}_{4} \mathrm{O}_{4} \mathrm{C}$. With formation of the gas phase, no equilibrium will be established at the melt/filter interface under vacuum conditions as shown by Equations (3) and (4). According to Equation (2), the melt partially reacts with the filter material to form mainly $\mathrm{Al}_{8} \mathrm{SiC}_{7}$ and $\mathrm{Al}_{4} \mathrm{O}_{4} \mathrm{C}$, but no gas. Therefore, it is possible that a stable and possibly protecting layer can be formed under ambient pressure conditions. The chemical stability of $\mathrm{Al}_{8} \mathrm{SiC}_{7}$ and $\mathrm{Al}_{4} \mathrm{O}_{4} \mathrm{C}$ against the aluminum melt at ambient pressure and a temperature of $740{ }^{\circ} \mathrm{C}$ was also investigated by thermodynamic calculations as follows, Equations (5) and (6):

$$
\begin{aligned}
0.5 \mathrm{~L}(\mathrm{Al}, \mathrm{Si}, \mathrm{Mg}) & +0.5 \mathrm{Al}_{4} \mathrm{O}_{4} \mathrm{C} \\
& \rightarrow 4.99 \times 10^{-1} \mathrm{~L}(\mathrm{Al}, \mathrm{Si}, \mathrm{Mg})+4.75 \times 10^{-1} \mathrm{Al}_{4} \mathrm{O}_{4} \mathrm{C}+1.92 \times 10^{-2} \text { spinel } \\
& +6.27 \times 10^{-3} \mathrm{Al}_{8} \mathrm{SiC}_{7} \\
0.5 \mathrm{~L}(\mathrm{AL}, \mathrm{Si}, \mathrm{Mg})+ & 0.5 \mathrm{Al}_{8} \mathrm{SiC}_{7} \rightarrow 0.5 \mathrm{~L}(\mathrm{Al}, \mathrm{Si}, \mathrm{Mg})+0.5 \mathrm{Al}_{8} \mathrm{SiC}_{7}
\end{aligned}
$$

As shown by Equations (5) and (6), $\mathrm{Al}_{4} \mathrm{O}_{4} \mathrm{C}$ and $\mathrm{Al}_{8} \mathrm{SiC}_{7}$ were mainly or completely stable against the melt. Based on these results, the formed interfacial layer should be relatively stable against aluminum melt at casting conditions under ambient pressure. However, at the beginning of the casting, the first interface will be a melt/filter/air interface. The results of the thermodynamic calculation for that case can be expressed by, Equation (7):

$$
\begin{aligned}
0.25 \mathrm{~L}(\mathrm{Al}, \mathrm{Si}, \mathrm{Mg}) & +0.25(0.79 \mathrm{Ar}+0.21 \mathrm{O})+0.5 \text { filter } \\
& \rightarrow 4.94 \times 10^{-1} \mathrm{Al}_{4} \mathrm{O}_{4} \mathrm{C}+2.25 \times 10^{-1} \mathrm{Al}_{8} \mathrm{SiC}_{7}+1.98 \times 10^{-1} \text { gas }(\mathrm{Ar}, \mathrm{Mg}, \mathrm{CO}) \\
& +2.69 \times 10^{-2} \mathrm{Al}_{4} \mathrm{C}_{4} \mathrm{Si}+4.55 \times 10^{-2} \text { graphite }+1.19 \times 10^{-2} \text { spinel }
\end{aligned}
$$

which showed that mainly $\mathrm{Al}_{4} \mathrm{O}_{4} \mathrm{C}$ and $\mathrm{Al}_{8} \mathrm{SiC}_{7}$ will be formed at the melt front during casting in contact with air.

\section{Discussion}

This study examined the filtration behavior of $\mathrm{Al}_{2} \mathrm{O}_{3}-\mathrm{C}$ filter with AlSi7Mg melt. These were complemented by thermodynamic calculations and wetting measurements. The wetting behavior of $\mathrm{Al}_{2} \mathrm{O}_{3}-\mathrm{C}$ substrates in contact with $\mathrm{AlSi7Mg}$ was evaluated by means of a conventional sessile drop test (vacuum, $950{ }^{\circ} \mathrm{C}$ and $180 \mathrm{~min}$ ) and a sessile drop test with capillary purification unit (vacuum, $730^{\circ} \mathrm{C}$ and $30 \mathrm{~min}$ ). The conventional sessile drop test yielded a contact angle of around $92^{\circ}$, contradicting the statement of the good slagging resistance due to poor wetting. The sessile drop measurement with capillary purification showed difficulties in measuring the contact angle due to the strong non-wetting behavior accompanied by rolling and jumping of the drop at the $\mathrm{Al}_{2} \mathrm{O}_{3}-\mathrm{C}$ substrate. A determination of the apparent contact angle of the rolling drop yielded a value of $157^{\circ}$, which is strongly non-wetting. The difference between the conventional sessile drop and the sessile drop with capillary purification explicitly proved the importance of the testing conditions for determination of the contact angle by 
aluminum melt. Sessile drop measurements at higher temperatures might enhance reactions not occurring within an industrial aluminum filtration setup.

Although the total level of inclusions in the aluminum melt before filtration was unavoidably different for the two industrially conducted filtration trials, there were significant differences between the filtration behavior of $\mathrm{Al}_{2} \mathrm{O}_{3}-\mathrm{C}$ filters and $\mathrm{Al}_{2} \mathrm{O}_{3}$ reference filters. For both filtration trials, the PoDFA index of the $\mathrm{Al}_{2} \mathrm{O}_{3}-\mathrm{C}$ filter sample was equal to half of the PoDFA index of the $\mathrm{Al}_{2} \mathrm{O}_{3}$ reference filter sample, indicating a significantly improved filtration when using $\mathrm{Al}_{2} \mathrm{O}_{3}-\mathrm{C}$ filter. Possible explanations for the improved filtration might be the reducing effect of the $\mathrm{Al}_{2} \mathrm{O}_{3}-\mathrm{C}$ or the strong non-wetting behavior between $\mathrm{Al}_{2} \mathrm{O}_{3}-\mathrm{C}$ and $\mathrm{AlSi7Mg}$, Voigt et al. [3].

Notable is the observation of a newly formed layer between the aluminum and the $\mathrm{Al}_{2} \mathrm{O}_{3}-\mathrm{C}$ coating, whereby such a layer was not identifiable in each trial. The layer possessed thicknesses between $10 \mu \mathrm{m}$ up to $50 \mu \mathrm{m}$ and consisted of $\mathrm{Al}, \mathrm{C}$, and $\mathrm{O}$. Additionally, thermodynamic calculations with parameters of the wetting and filtration trials were conducted and revealed the formation of an $\mathrm{Al}_{4} \mathrm{O}_{4} \mathrm{C}$ phase. This was in accordance with the detected $\mathrm{Al}, \mathrm{C}$, and $\mathrm{O}$ layers. The thermodynamically predicted phase $\mathrm{Al}_{8} \mathrm{SiC}_{7}$ could not be detected at the interface between the solidified aluminum melt and the $\mathrm{Al}_{2} \mathrm{O}_{3}-\mathrm{C}$ filters, neither by EBSD nor by EDX.

\section{Conclusions}

The wetting behavior performed by two different methods and filtration behavior of $\mathrm{Al}_{2} \mathrm{O}_{3}-\mathrm{C}$ filters estimated by PoDFA analysis has been measured and compared to the behavior of standard $\mathrm{Al}_{2} \mathrm{O}_{3}$ filters.

$\mathrm{Al}_{2} \mathrm{O}_{3}-\mathrm{C}$ filters are shown to be more effective concerning the removal of non-metallic inclusions from the aluminum alloy AlSi7Mg melts when using the developed casting system with a sand mold. Additional investigations are necessary to verify the results, to understand the complex filtration mechanism of the $\mathrm{Al}_{2} \mathrm{O}_{3}-\mathrm{C}$ filters and distinguish between the filtration performance of the two different $\mathrm{Al}_{2} \mathrm{O}_{3}-\mathrm{C}$ materials coked at $800{ }^{\circ} \mathrm{C}$ and $1400{ }^{\circ} \mathrm{C}$ respectively. The surface morphology as well as phase characteristics have to be taken into account.

Author Contributions: C.G.A.: Writing—Review \& Editing, Funding Acquisition, Supervision, Conceptualization; A.C.: Writing-Review \& Editing, Supervision, Investigation; M.S.: Writing—Review \& Editing, Funding Acquisition, Supervision; B.F.: Formal Analysis, Investigation of the contact angles, Writing-Review \& Editing; T.Z.: Investigation of the thermodynamic calculations, Writing-Review \& Editing Supervision; J.H.: Writing-Review \& Editing, Conceptualization; C.V.: Methodology, Investigation, Writing—Original Draft, Writing-Review \& Editing, Preparation, Conceptualization. All authors have read and agreed to the published version of the manuscript.

Funding: This research was funded by the German Research Foundation (DFG), grant number 169148856.

Acknowledgments: The authors would like to thank the German Research Foundation (DFG) for supporting these investigations as part of the Collaborative Research Centre 920 "Multi-Functional Filters for Metal Melt Filtration-A Contribution towards Zero Defect Materials" (Project-ID 169148856) sub-projects A02, C06 and S03. The authors would also like to acknowledge the support of Alina Schramm (C06), Dr. Gert Schmidt, Natalia Sobczak and Rafał Nowak.

Conflicts of Interest: The authors declare no conflict of interest. The sponsors had no role in the design, execution, interpretation, or writing of the study.

\section{References}

1. Olson, R.A.; Martins, L.C.B. Cellular ceramics in metal filtration. Adv. Eng. Mater. 2005, 7, 187-192. [CrossRef]

2. Kondrat'Ev, A.S.; Popov, V.N.; Aksel'Rod, L.M.; Baranovskii, M.R.; Suvorov, S.A.; Tebuev, N.B. Possibilities of filter-refining of metals and the required characteristics of the filter elements: A review. Refract. Ind. Ceram. 1990, 31, 384-391. [CrossRef]

3. Voigt, C.; Ditscherlein, L.; Werzner, E.; Zienert, T.; Nowak, R.; Peuker, U.; Sobczak, N.; Aneziris, C.G. Wettability of AlSi7Mg alloy on alumina, spinel, mullite and rutile and its influence on the aluminum melt filtration efficiency. Mater. Des. 2018, 150, 75-85. [CrossRef] 
4. Routschka, G.; Wuthnow, H. Handbook of Refractory Materials; Vulkan-Verlag Essen: Essen, Germany, 2012; ISBN 380273162X.

5. Emmel, M.; Aneziris, C.G. Development of novel carbon bonded filter compositions for steel melt filtration. Ceram. Int. 2012, 38, 5165-5173. [CrossRef]

6. Luchini, B.; Hubálková, J.; Wetzig, T.; Grabenhorst, J.; Fruhstorfer, J.; Pandolfelli, V.; Aneziris, C. Carbon-bonded alumina foam filters produced by centrifugation: A route towards improved homogeneity. Ceram. Int. 2018, 44, 13832-13840. [CrossRef]

7. Eustathopoulos, N.; Nicholas, M.G.; Drevet, B. Wettability at High Temperatures; Pergamon: Oxford, UK, 1999; ISBN 9780080421469.

8. Bao, S.; Tang, K.; Kvithyld, A.; Tangstad, M.; Engh, T.A. Wettability of aluminum on alumina. Met. Mater. Trans. B 2011, 42, 1358-1366. [CrossRef]

9. Sobczak, N.; Singh, M.; Asthana, R. High-temperature wettability measurements in metal/ceramic systems-Some methodological issues. Curr. Opin. Solid State Mater. Sci. 2005, 9, 241-253. [CrossRef]

10. Shen, P.; Fujii, H.; Matsumoto, T.; Nogi, K. Critical factors affecting the wettability of $\alpha$-alumina by molten aluminum. J. Am. Ceram. Soc. 2004, 87, 2151-2159. [CrossRef]

11. Fankhänel, B.; Stelter, M.; Voigt, C.; Aneziris, C.G. Interaction of AlSi7Mg with oxide ceramics. Adv. Eng. Mater. 2017, 19, 1700084. [CrossRef]

12. Damoah, L.; Zhang, L. Removal of inclusions from aluminum through filtration. Met. Mater. Trans. B 2010, 41, 886-907. [CrossRef]

13. Görner, H.; Syvertsen, M.; Øvrelid, E.J.; Engh, T.A. AlF3 as an aluminium filter medium. Light Metals 2005, 939-944.

14. Zhou, M.; Shu, D.; Li, K.; Zhang, W.Y.; Ni, H.J.; Sun, B.D.; Wang, J. Deep filtration of molten aluminum using ceramic foam filters and ceramic particles with active coatings. Met. Mater. Trans. B 2003, 34, 1183-1191. [CrossRef]

15. Luyten, J.; Vandermeulen, W.; De Schutter, F.; Simensen, C.; Ryckeboer, M. Ceramic foams for Al-recycling. Adv. Eng. Mater. 2006, 8, 705-707. [CrossRef]

16. Syvertsen, M.; Kvithyld, A.; Bao, S.; Nordmark, A.; Johansson, A. Parallel laboratory and industrial scale aluminium filtration tests with $\mathrm{Al}_{2} \mathrm{O}_{3}$ and $\mathrm{SiC}$ based CFF filters. Light Metals 2014, 1041-1046. [CrossRef]

17. Voigt, C.; Jäckel, E.; Taina, F.; Zienert, T.; Salomon, A.; Wolf, G.; Aneziris, C.G.; Le Brun, P. Filtration efficiency of functionalized ceramic foam filters for aluminum melt filtration. Met. Mater. Trans. B 2017, 48, 497-505. [CrossRef]

18. Voigt, C.; Dietrich, B.; Badowski, M.; Gorshunova, M.; Wolf, G.; Aneziris, C.G. Impact of the filter roughness on the filtration efficiency for aluminum melt filtration. Light Metals 2019, 1063-1069. [CrossRef]

19. Utigard, T.A.; Sommerville, I. Cleanliness of aluminum and steel: A comparison of assessment methods. Light Metals 2005, 951-956.

20. Canullo, M.; Labaton, M.F.J.; Laje, R.A. Cleanliness of primary A356 alloy: Interpretation and standardisation of PODFA laboratory measurements. In Proceedings of the Aluminum Cast House Technology: 8th Australasian Conference TMS, Brisbane, Australia, 14-17 September 2003; pp. 341-355. [CrossRef]

21. Bianconi, A.; Bachrach, R.Z.; Hagstrom, S.B.M.; Flodström, S.A. Al- Al2O3 interface study using surface soft-x-ray absorption and photoemission spectroscopy. Phys. Rev. B 1979, 19, 2837-2843. [CrossRef]

22. Sobczak, N.; Asthana, R.; Radziwill, W.; Nowak, R.; Kudyba, A. The role of aluminum oxidation in the wetting-bonding relationship of Al/oxide couples. Arch. Metall. Mater. 2007, 52, 55-65. [CrossRef]

23. Andersson, J.O.; Helander, T.; Höglund, L.; Shi, P.; Sundman, B. Thermo-Calc \& DICTRA, computational tools for materials science. Calphad 2002, 26, 273-312. [CrossRef]

24. Salomon, A.; Zienert, T.; Voigt, C.; Jäckel, E.; Fabrichnaya, O.; Rafaja, D. Comparison of interfacial reactions between AlSi7Mg and alumina filter after casting and spark plasma sintering**. Adv. Eng. Mater. 2013, 15, 1206-1215. [CrossRef]

25. Zienert, T.; Fabrichnaya, O. Phase relations in the A356 alloy: Experimental study and thermodynamic calculations. Adv. Eng. Mater. 2013, 15, 1244-1250. [CrossRef]

26. Gröbner, J.; Lukas, H.L.; Aldinger, F. Thermodynamic calculation of the ternary system Al-Si-C. Calphad 1996, 20, 247-254. [CrossRef]

(C) 2020 by the authors. Licensee MDPI, Basel, Switzerland. This article is an open access article distributed under the terms and conditions of the Creative Commons Attribution (CC BY) license (http://creativecommons.org/licenses/by/4.0/). 